\title{
SHARIAH COMPLIANCE PADA INVESTASI SUKUK DALAM SECURITIES CROWDFUNDING DI INDONESIA
}

\author{
Muhammad Rusydi Kadir
}

1 Program Magister Hukum Bisnis Syariah, Universitas Islam Negeri Sunan Kalijaga Yogyakarta, Mrusdi648@gmail.com

\section{ABSTRAK}

Teknologi di Indonesia semakin tidak terbendung
menerangkan peradaban semakin maju, tidak terkecuali bidang ekonomi mengalami perkembangan yang sangat cepat dalam bentuk sistemnya, terlihat dengan adanya system baru yang disebut dengan securities crowdfunding. Maka dari itu pemerintah telah mengeluarkan aturan yang mendasari setiap kegiatan tersebut melalui POJK nomor 57 tahun 2020. Securities crowdfunding memiliki 3 jenis produk yaitu efek ekuitas, efek utang, dan efek syariah (sukuk). Aturan securities crowdfunding tidak membahas secara rinci mengenai efek syariah (sukuk), sehingga keterlibatan dan kedudukan DSN-MUI tidak diketahui dalam menciptakan investasi sukuk yang bebas dari unsur riba', maysir, dan gharar. Penelitian ini menggunakan pendekatan normatif konseptual sekaligus mengkoherensikan anatar aturan dengan shariah compliance
INFORMASI

ARTIKEL

Katakunci:

securities

crowdfunding,

peraturan, sukuk 


\section{PENDAHULUAN}

Kemajuan teknologi sudah dirasakan hampir seluruh ummat manusia dimuka bumi terkhusus Indonesia hasil revolusi Industry 4.0 dan Social 5.0 menjadi sentrum dalam menjalankan kegiatan politik, ekonomi, sosial, bahkan dalam lingkungan Pendidikan. Memajukan masyarakat sosial dalam penggunaan teknologi sebagai bagian dari kelompok interakasi yang mampu memberikan manfaat satu sama lain dengan system yang mudah, efesian, dan cepat. ${ }^{1}$

Dinamika kehidupan masyarakat dewasa ini, telah melahirkan pola pemikiran baru yang turut berkembang seiring dengan kemajuan zaman. Ketika mekanisme pembayaran dituntut untuk selalu mengakomodir setiap kebutuhan masyarakat dalam hal perpindahan dana secara cepat, aman dan efisien, maka inovasi-inovasi teknologi pembayaran semakin bermunculan dengan sangat pesat. $^{2}$

Dalam lingkup perekonomian, Perusahaan-perusahaan kini menggunakan bantuan internet yang terkoneksi untuk menjalankan transaksi pasar modal sehingga mampu memberikan kemanfaatan antara perusahaan dengan individu pemodal. Kegiatan tolong-menolong sesama manusia menjadikan teknologi informasi sebagai alat sentral (Platform Crowdfunding) dalam membantu

1 Iswi Hariyani dan Cita Yustisia, Kajian Hukum Bisnis Jasa Crowdfunding Properti, Jurnal; Legislasi Indonesia Vol 16 No.1, Maret 2019, hlm. 43.

2 Sahrul Gunawan, Malkan, Abdul Jalil (2019). Peranan Kantor Perwakilan Bank Indonesia Provinsi Sulawesi Tengah Dalam Upaya Meningkatkan Penggunaan Uang Logam. Jurnal Ilmu Perbankan dan Keuangan Syariah, 1(1), 57-72. masyrakat perkotaan ataupun terpencil untuk menginformasikan dan menerima dukungan dana secara luas seperti platform ayodukung.com, kitabisa.com, dan lainnya.

Platform yang bergerak dibidang ekonomi telah banyak digambarkan melalui aplikasi dengan maksud mendukung ekonomi kelas bawah atau usaha kecil menengah (UKM) menggunakan produk-produk ayang ada dipasar modal, demi meningkatkan kesejahteraan UKM. Dengan perkembangan ini, pemerintah melalui Otoritas Jasa Keuangan (OJK) mengelaurkan peraturan yang mengatur tentang kegiatan efek termasuk yang berbasis syariah, semuanya tergabung dalam POJK nomor 57 tahun 2020. Namun penulis telah melakukan observasi terhadap aturan tersebut dan menemukan beberapa hal yang perlu diperhatikan dalam aturan mengenai efek syariah atau sukuk.

OJK melalui peraturan No. 57 /POJK.04/2020 tentang securities crowdfunding akan mengizikan jika telah melengkapi semua dokumen perizinan yang disiapkan oleh penyelenggara. Dalam pasal 13 huruf o menyebutkan, bahwa penyelenggara memiliki surat pernyataan yang menyatakan akan menunjuk pihak yang bertanggung jawab melakukan pengawasan terkait dengan pemenuhan prinsip syariah di pasar modal dalam hal Penyelenggara melayani penawaran Sukuk oleh Penerbit melalui Layanan Urun Dana, jika Penyelenggara tidak memiliki dewan pengawas syariah. ${ }^{3}$

3 Pasal 13 Peraturan OJK No. 57 /POJK.04/2020 tentang Penawaran Efek Melalui Layanan Urun Dana Berbasis Teknologi Informasi (Securities Crowdfunding). 
Sedangkan, dalam Kompilasi Hukum Ekonomi Syariah (KHES) bahwa Emiten atau pihak yang melakukan penawaran umum dalam hal securities crowdfunding dapat dipersamakan dengan penyelenggara, jika bermaksud menerbitkan efek syariah wajib menandatangani dan memenuhi ketentuan transaksi yang sesuai dengan syariah atas efek syariah yang dikeluarkan. Emiten yang menerbitkan efek syariah wajib menjamin bahwa kegiatan usahanya memenuhi prinsip syariah dan memiliki shariah compliance officer. ${ }^{4}$

Kontradiksi pelaksanaan shariah compliance officer sangat berpengaruh terhadap penertiban dan kedisiplinan system dan pelaksanaan efek syariah ${ }^{5}$ dalam securities crowdfunding di Indonesia. Melihat aturan diatas maka penting bagi penulis untuk melakukan melakukan penelitian tersebut, untuk melihat sejau mana sukuk dalam securities crowdfunding menjaga kegiatannya sesuai dengan prinsip syariah.

\section{TINJAUAN PUSTAKA}

\subsection{Pengertian Sukuk}

Sukuk atau dapat dikenal juga dengan sebutan efek Syariah, merupakan transaksi yang sudah banyak dikeanl dalam dunia investasi, Sukuk adalah suatu surat berharga

\footnotetext{
4 Pasal 576 Kompilasi hokum Ekonomi Syari'ah, Buku II, edisi 2011.

5 Nurdin, N., \& Mir'atun, M. a. (2018). Do Government And Private Sharia Commercial Banks Practice Similar Financial Social Responsibility Disclosure. Hunafa: Jurnal Studia Islamika, 15(2), 285-321.
}

jangka panjang berdasarkan prinsip Syariah yang dikeluarkan Emiten kepada pemegang obligasi Syariah yang mewajibkan Emiten untuk membayar pendapatan kepada pemegang obligasi Syariah berupa bagi hasil/margin/fee serta membayar kembali dana obligasi pada saat jatuh tempo penyataan ini adalah definisi obligasi Syariah menurut Dewan Syariah Nasional (DSN) No. 32/DSNMUI/ IX/2002.

a. Menurut Accounting and Auditing Organization for Islamic Financial Institution (AAOIFI, 2002), sukuk adalah sertifikat yang menunjukkan nilai yang sama setelah penutupan subscription, penerimaan dari nilai atas sertifikat dan meletakkannya untuk digunakan sebagaimana rencana, pemilikan saham dan hak atas aset yang nampak, penggunaan dan jasa, dan equity atas proyek yang disebutkan atau equity atas aktivitas tertentu.

b. Menurut Keputusan Ketua Badan Pengawas Pasar Modal dan Lembaga Keuangan (BAPEPAM) No. KEP130/BL/2006 Tahun 2006 Peraturan No.IX.A.13, sukuk adalah efek Syariah berupa sertifikat atau bukti kepemilikan yang bernilai sama dan mewakili bagian penyertaan yang tidak terpisahkan atau tidak terbagi atas: kepemilikan aset berwujud tertentu, nilai manfaat dan jasa atas aset proyek tertentu atau aktivitas investasi tertentu, dan kepemilikan atas aset proyek tertentu atau aktivitas investasi tertentu.

c. Menurut Undang-Undang Surat Berharga Syariah Negara (SBSN), sukuk adalah surat berharga yang diterbitakan berdasarkan Syariah islam sebagai bukti penyertaan atas aset SBSN baik dalam bentuk mata 
uang rupiah maupun mata uang asing.

Jenis sukuk yang ada di Indonesia sesuai dengan fatwa yang diterbitkan Dewan Syariah Nasional salah satunya adalah sukuk ijárah. Namun, berdasarkan Standar Syariah The Accounting and Auditing Organization for Islamic Financial Institutons (AAOIFI), sukuk dibagi menjadi sembilan jenis, yaitu:

1. Sukuk Ijarah, adalah akad pemindahan hak guna atas barang atau jasa, tanpa diikuti dengan pemindahan kepemilikan barang atau jasa itu sendiri. Sukuk Ijarah adalah sukuk yang diterbitkan berdasarkan akad ijarah. Sukuk Ijarah terdiri dari; sukuk kepemilikan aset berwujud yang disewakan, sukuk kepemilikan manfaat dan sukuk kepemilikan jasa.

2. Sukuk Mudharabah, adalah sukuk yang diterbitkan berdasarkan perjanjian atau akad mudharabah dimana satu pihak menyediakan modal (rab almaal) dan pihak lain menyediakan tenaga dan keahlian (mudharib), keuntungan dari kerja sama tersebut akan dibagi berdasarkan perbandingan yang telah disetujui sebelumnya. Kerugian yang timbul akan ditanggung sepenuhnya oleh pihak yang menjadi penyedia modal.

3. Sukuk Salam, adalah sukuk yang diterbitkan dengan tujuan untuk mendapatkan dana untuk modal dalam akad salam, sehingga barang yang akan disediakan melalui akad salam menjadi milik pemegang sukuk.

4. Sukuk Musyarakah, adalah sukuk yang diterbitkan berdasarkan perjanjian atau akad musyarakah dimana dua pihak atau lebih bekerja sama menggabungkan modal untuk membangun proyek baru, mengembangkan proyek yang telah ada, atau membiayai kegiatan usaha. Keuntungan maupun kerugian yang timbul ditanggung bersama sesuai dengan jumlah partisipasi modal masing-masing pihak.

5. Sukuk Istishna', adalah sukuk yang diterbitkan berdasarkan perjanjian atau akadistishna' dimana para pihak menyepakati jual-beli dalam rangka pembiayaan suatu proyek/barang. Adapun harga, waktu penyerahan, dan spesifikasi proyek/barang ditentukan terlebih dahulu berdasarkan kesepakatan.

6. Sukuk Murabaha. adalah sukuk yg diterbitkan berdasarkan prinsip jualbeli, penerbit sertifikat sukuk adalah penjual komoditi, sedangkan investornya adalah pembeli komoditi tersebut.

7. Sukuk Wakalah, adalah sukuk yang merepresentasikan suatu proyek atau kegiatan usaha yang dikelola berdasarkan akad wakalah, dengan menunjuk agen (wakil) tertentu untuk mengelola usaha atas nama pemegang sukuk.

8. Sukuk Muzara'ah, adalah sukuk yang diterbitkan dengan tujuan mendapatkan dana untuk membiayai kegiatan pertanian berdasarkan akad muzara'ah, sehingga pemegang sukuk berhak atas bagian dari hasil panen sesuai dengan ketentuanketentuan dalam perjanjian.

9. Sukuk Musaqah, adalah sukuk yang diterbitkan dengan tujuan menggunakan dana hasil penerbitan sukuk untuk melakukan kegiatan irigasi atas tanaman berbuah, membayar biaya operasional dan perawatan tanaman tersebut berdasarkan akad musaqah, dengan demikian pemegang sukuk berhak 
atas bagian dari hasil panen sesuai kesepakatan.

\subsection{Pengertian Securities Crowdfunding}

Crowdfunding adalah ketika bisnis, organisasi atau individu mendanai proyek atau usaha dengan sumbangan kecil dari banyak orang. Sederhananya kerumunan orang akan mendanai proyek atau bisnis, daripada didanai oleh satu atau dua investor besar. 6 yang diperlukan untuk arus pemasukkan kas, cara dan usaha ini akan menarik banyak orang yang ingin membantu mendanai sebuah proyek. Sebagian besar kampanye seperti ini terjadi melalui platform internet dan telah menetapkan kerangka waktu kapan uang dapat dinaikkan dan mengungkapkan tujuan moneter tertentu.

Peserta atau pendukung, dijanjikan akan mendapat sejumlah uang minimum dari dana dan akan menerima hadiah atas kontribusi mereka. Hadiah umumnya bervariasi berdasarkan ukuran donasi yang juga memberi insentif pada donasi yang lebih tinggi. Sementara beberapa kampanye crowdfunding tidak memungkinkan para pendukung untuk memiliki sebagian dari perusahaan yang mereka dukung. Seperti jenis crowdfunding ekuitas yang memungkinkan usaha kecil dan pemula memberikan sebagian dari perusahaan mereka.

Pada dasarnya, Crowdfunding juga mempunyai beberapa jenis dan cirinya tersendiri. Berikut ini adalah jenis atau

6https://idcloudhost.com/crowdfundin g-pengertian-ciri-ciri-syarat-dan-contohnya. Diakses 2 Juni 2021. tipe- tipe dari sebuah Crowdfunding7 : Crowdfunding berbasis investasi. Crowdfunding tipe ini adalah dimana Anda berinvestasi dalam bisnis dan menerima imbalan sebagai imbalan yang biasanya berupa saham. Crowdfunding berbasis pinjaman. Anda meminjamkan uang kepada individu atau perusahaan dengan imbalan tingkat bunga yang ditetapkan. Ini juga disebut pinjaman peer-to-peer atau peer-to-business (P2P atau P2B). Crowdfunding berbasis donasi. Di sini donor berkontribusi pada jumlah total untuk proyek baru. Seringkali para donor dijanjikan pengembalian dalam bentuk produk atau layanan yang akan dikembangkan dengan pendapatan yang dibawa oleh kampanye crowdfunding. Untuk proyek amal yang penerima manfaat utamanya bukan donor, mungkin ada beberapa keuntungan atau hadiah lain bagi pemberi dana. Crowdfunding berbasis hadiah. Jika Anda memberikan uang sebagai imbalan atas imbalan yang dikaitkan dengan sebuah proyek atau menyebabkan Anda mendukungnya, maka ini adalah tipe crowdfunding yang berbasis hadiah.

\footnotetext{
7 https:/ /accurate.id/ekonomi-
} keuangan/crowdfunding-tujuan-jenis-danmanfaatnya-pada-ekonomi-bisnis/Diakses 2 Juni 2021. 
1. Crowdfunding investasi

Tipe ini adalah di mana bisnis mencari modal menjual kepemilikan dipertaruhkan online dalam bentuk ekuitas atau hutang. Disini, individu yang mendanai menjadi pemilik atau pemegang saham dan memiliki potensi pengembalian finansial, tidak seperti dalam model donasi. Semua ini menjadi mungkin ketika Judul II UU JOBS mulai berlaku pada September 2013 untuk investor terakreditasi dan organisasi nirlaba umumnya tidak dapat memanfaatkan pasar ekuitas.

Crowdfunding dalam upaya eningkatkan modal usaha mampu menghasilkan manfaat yang bisa dicapai secara mudah. Namun, berbagai kekurangannya juga tidak bisa dianggap biasa. Berikut ini adalah kekurangan dan keunggulan dari Crowdfunding.

\section{Keunggulan Crowdfunding}

1. Profil bisnis ataupun produk yang dibungkus dengan cara menarik akan menjadi nilai lebih untuk perusahaan Anda

2. Adanya keikutsertaan banyak orang dalam sistem Crowdfunding akan mampu menghasilkan ruang tersendiri dimana pemilik bisnis mampu berinteraksi langsung dengan mereka.

3. Adanya timbal balik yang menawarkan suatu akses pra-rilis pada konten ataupun peluang guna mengulas suatu konten beta pada para investor sebagai bagian dari insentif pendanaan.

4. Akan menghasilkan keuntungan ekonomi bagi pemilik usaha

\section{METHODOLOGY}

Dalam penulisan karya ilmiah ini, penulis menggunakan metode Yaitu penelitian hukum normatif, penelitian hukum normatif-empiris, dan penelitian hukum empiris. Ketiga jenis tersebut dapat digunakan dalam kasus hukum berupa peristiwa hukum atau berupa produk hukum. ${ }^{8}$ Penulis akan menggunakan jenis penelitian hukum normatif (Normative law research) jenis ini dapat memfokuskan penelitian pada inventaris hukum positif, asas-asas dan doktrin hukum, sinkronisasi hukum, sistematika hukum, perbandingan hukum, dan sejarah hukum.

Adapun sifat dan tujuan penelitian yakni deskriptif, sifat ini untuk memperoleh gambaran lengkap tentang keadaan hukum yang berlaku ditempat tertentu, atau mengenai gejala yuridis yang ada, atau peristiwa hukum tertentu yang terjadi saat ini dimasyarakat. ${ }^{9}$ sidat penelitian ini digunakan untuk medapatkan gambaran hukum yang berkaitan dengan efek pada securities crowdfunding.

Jenis pendekatan dalam penelitian hukum, yakni pendekatan Undangundang (statute approach), pendekatan kasus (case approach), pendekatan historis (historical approach), pendekatan komparatif (comparative approach, dan pendekatan konseptual (conceptual approach). ${ }^{10}$ Peneliti dalam hal ini akan menggunakan pendekatan pendekatan konseptual (conceptual approach), pendekataan konseptual dilakukan untuk membahas pendapat para pakar dalam tulisan dan artikel yang telah dimuat. Pendekatan ini menjawab konsep-konsep sekaligus pendukung

8 AbdulKadir Muhammad, Hukum dan Penelitian Hukum, Cet. 1, Bandung: PT Citra Aditya Bakti, 2004, hlm. 52.

${ }^{9}$ Ibid., hlm. 49.

10 Peter Mahmud Marzuki, Penelitian Hukum, Cet. 2, Jakarta: Kencana 2008, hlm. 93. 
dari bentuk pendekatan undangundang.

\section{HASIL DAN PEMBAHASAN}

4.1 Regulasi Sukuk di Indonesia

QS Al-Bāqarah ayat 261

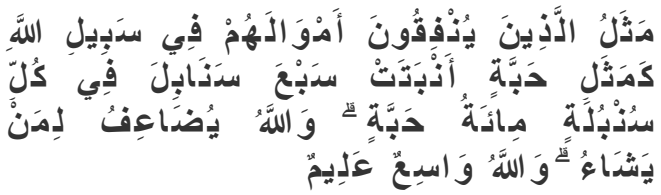

Terjemahannya:

"Perumpamaan orang yang menginfakkan hartanya di jalan Allah seperti sebutir biji yang menumbuhkan tujuh tangkai, pada setiap tangkai ada seratus biji. Allah melipatgandakan bagi siapa yang Dia kehendaki, dan Allah Mahaluas, Maha Mengetahui."

Ayat ini mengumpamakan bagi orang-orang yang menahan diri untuk tidak menikmati seketika harta yang dimilikinya dan menyisihkannya dalam bentuk infak maka Allah akan melipatgandakannya sampai 700 kali lipat dari modal yang ditanamkan dalam bentuk infak. Menurut Said Ibnu Jābir dalam tafsir Ibnu Kastir mengatakan bahwa yang dimaksud dengan jalan Allah adalah dalam rangka menambah ketaatan kepada Allah SWT. ${ }^{11}$

Dalam pandangan ekonomi, ayat diatas diartikan dengan penundaan keinginan, yakni menyisihkan sesuatu yang kita miliki sekarang untuk digunakan dikemudian hari, artinya menyiapkan suatu perbekalangan untuk

11 Al-Imam Abul Fida Isma'il Ibnu Katsir Ad-Dimasyqi, Tafsir Ibnu Katsir Juz 3 (Jakarta: Pustaka Imam Asy-Syafi'i, 2003). h, 7475 dimasa yang akan datang. 12 "Tentang tujuh ekor sapi betina yang gemuk yang dimakan oleh tujuh (ekor sapi betina) yang kurus, tujuh tangkai (gandum) yang hijau dan (tujuh tangkai) lainnya yang kering" diarikan bahwa tidak selamanya kondisi keuangan kita dalam keadaan yang baik, sehingga untuk mensiasatinya kita dituntut untuk bias mengatur harta kekayaan yang kita miliki sehingga tidak dihabiskan atau berpoya-poya dikala kita memiliki kelebihan harta. Akan tetapi diharusnya memiliki tabungan dalam bentuk investasi untuk dapat menikmati hasilnya dikemudian hari disaat usaha atau diri kita tidak seproduktif dulu lagi (pensiun atau disaat genting). ${ }^{13}$

Q.S. al-Ma'idah ayat 1

$$
5
$$

Terjemahan:

"Hai orang yang beriman! Penuhilah akad-akad itu..."

Q.S. al-Isra' ayat 34

$$
6
$$

Terjemahan:

"dan penuhilah janji, sesungguhnya janji itu pasti dimintai pertanggungjawabannya."

12 Beta Pujangga Mukti, "Strategi Ketahanan Pangan Nabi Yusuf: Studi Analisis tentang Sistem Ketahanan Pangan Nabi Yusuf dalam Al-Quran Surat Yusuf Ayat: 46-49," TARJIH: Jurnal Tarjih dan Pengembangan Pemikiran Islam, 16.1 (2019). Hlm. 44-45.

13 Anna Nurlita, "Investasi Di Pasar Modal Syariah Dalam Kajian Islam," Kutubkhanah: Jurnal Penelitian Sosial Keagamaan, 17.1 (2015),Hlm 1-20

e-ISSN: 2686-6625 
Hadīs Rasulullah Muhammad SAW yang diriwatyatkan oleh Imam alBukhāri "Bahwasannya Rasulullah Shallallahu 'Alaihi wa Sallam menyerahkan kepada yahudi Khaibar kebun kurma di Khaibar dan ladangnya supaya mereka bekerja padanya dengan biaya dari mereka sendiri, dan untuk Rasulullah Shallallahu 'Alaihi wa Sallam setengah dari hasil panennya." Hadīs ini menjelaskan betapa nabi telah memberikan contoh kepada kita tentang kegiatan investasi yang sama-sama menguntungkan. Dalam hal investasi tentu tidak boleh merugikan salah satu pihak, baik dari pemodal maupun pengelola modal harus menganut asas keriḍān satu sama lain. ${ }^{14}$

Agus Triyanta tentang "Gharar; Konsep dan Penghindarannya pada Regulasi Terkait Screening Criteria di Jakarta Islamic Index" Disini agus triyanta menjelaskan aspek-aspek utama yang membedakan antara pasar modal dan pasar modal syariah adalah ketiadaan unsur spekulasi dalam hukum islam biasanya disebut dengan gharar, di dalam instrumen bisnis yang ditawarkan. ${ }^{15} \mathrm{Di}$ Indonesia upaya hukum yang dilakukan untuk menghindari spekulasi pada kegiatan pasar modal diatur melalui fatwa Dewan Syariah Nasional Majelis Ulama' Indonesia.

Fatwa dewan syariah Nasional No. 32/DSN-MUI/IX/2002, tentang Obligasi syari'ah adalah surat berharga

14 Diana Wiyanti, "Perspektif Hukum Islam terhadap Pasar Modal Syariah Sebagai Alternatif Investasi Bagi Investor," Ius Quia Iustum Law Journal, 20.2 (2013), 234-54

15 Agus Triyanta, "Gharar: Konsep dan Penghindarannya pada Regulasi Terkait Screening Criteria di Jakarta Islamic Index", dalam Jurnal Hukum No. 4 Vol. 172010. berjangka panjang berdasarkan prinsip Syariah yang dikelurkan emitten kepada pemegang obligasi Syariah, tersebut berupa bagi hasil/margin/fee, serta membyar kembali dana obligasi pada saat jatuh tempo. Kini tepat September 2020 Dewan Syariah Nasional Majelis Ulama' Indoensia mengeluarkan fatwa terbaru mengenai investasi sukuk, Fatwa tersebut tertuang dalam DSNMUI nomor 137/IX/2020. Didalamnya mengatur macam-macam akad yang dapat digunakan sukuk.

\subsection{Fatwa Dsn-Mui Tentang Crownfunding}

Majelis Ulama' Indonesia belum menetapkan atau mengeluarkan fatwa secara khusus mengenai layanan urun dana berbasis tekhnologi informasi (Equity Crowdfunding) tapi pada prinsipnya telah diatur dalam Fatwa DSN MUI Nomor 117 Tahun 2018 tentang Layanan pembiayaan berbasis tekhnologi.

$\begin{array}{lrr}\text { Model layanan } & \text { pembiayaan } \\ \text { berbasis } & \text { teknologi } & \text { informasi }\end{array}$ berdasarkan prinsip syariah yang dibahas dalam Fatwa MUI Nomor 117/2018, yakni mengenai:

1. Pembiayaan anjak piutang (factoring); yaitu pembiayaan dalam bentuk jasa pengurusan penagihan piutang berdasarkan bukti tagihan (invoice), baik disertai atau tanpa disertai talangan (qardh) yang diberikan kepada pelaku usaha yang memiliki tagihan kepada pihak ketiga (payor).

2. Pembiayaan Pengadaan Barang pesanan Pihak Ketiga (Purchase Order); yaitu pembiayaan yang diberikan kepada pelaku usaha yang telah memperoleh pesanan atau surat perintah kerja pengadaan barang dari pihak ketiga. 
3. Pembiayaan Pengadaan barang untuk pelaku usaha yang berjualan secara online (online seller); yaitu pembiayaan yang diberikan kepada pelaku usaha yang melakukan transaksi jual beli online

4. Pembiayaan pengadaan barang untuk pelaku usaha yang berjualan secara online dengan pembayaran melalui penyelenggara payment gateway, yaitu pembiayaan yang diberikan kepada pelaku usaha (seller) yang aktif berjualan secara online melalui saluran distribusi (channel distribution) yang dikeiolanya sendiri dan pembayarannya dilakukan melalui penyedia jasa otorisasi pembayaran secara online (payment gateway) yang bekerjasama dengan pihak Penyelenggara.

5. Pembiayaan untuk Pegawai (Employee), yaitu pembiayaan yang diberikan kepada pegawai yang membutuhkan pembiayaan konsumtif dengan skema kerjasama potong gaji melalui institusi pemberi kerja.

Pembiayaan berbasis komunitas (community based), yaitu pembiayaan yang diberikan kepada anggota komunitas yang membutuhkan pembiayaan, dengan skema pembayarannya dikoordinasikan melalui koordinator/pengurus komunitas. ${ }^{16}$

Q.S Annisa' ayat 29:

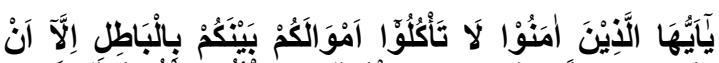

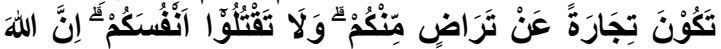

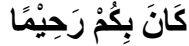

Terjemahan :

\footnotetext{
16 Fatwa Dewan Syari'ah Nasional nomor 117 tahun 2018. Hal 9-10
}

"Wahai orang-orang yang beriman! Janganlah kamu saling memakan harta sesamamu dengan jalan yang batil (tidak benar), kecuali dalam perdagangan yang berlaku atas dasar suka sama suka di antara kamu. Dan janganlah kamu membunuh dirimu. Sungguh, Allah Maha Penyayang kepadamu".

Islam sebagai agama yang sempurna, datang dengan membawa ajaran yang universal dan komprehensif bagi seluruh aspek kehidupan manusia, baik aspek individual maupun sosial. Sehingga ajaran Islam tidak hanya mengatur seorang hamba supaya berindividual yang Islami tetapi juga bersosial yang Islami. Bahkan, bersosial Islami ini tidak hanya kepada sesama muslim tetapi juga kepada non muslim. ${ }^{17}$

Ayat diatas sudah sering menjadi rujukan dalam hubungan sesama manusia para ulama' menjadikan ayat diatas sebagai landasan yuridis dalam menjawab persoalan yang belum ada hukum dan kaidahnya termasuk Dewan Syariah Nasional dalam membuat fatwa terbaru.

Berkaitan dengan Surat An-Nisa' Ayat 29 ini, Ibn Katsīr menjelaskan bahwa Allah Ta'ala telah melarang hamba-hamba-Nya yang beriman dari memakan harta orang lain dengan cara yang batil. Yaitu segala bentuk usaha mendatangkan harta yang tidak disyariatkan seperti riba dengan segala variannya, perjudian, dan seluruh bentuk transaksi yang mengandung penipuan dan spekulasi. Walaupun secara lahir hukum syar'inya hanya

17 Ade Wahidin. (2018). Tinjauan dan Hukum Tasyabbuh Perspektif Empat Imam Mazhab, AL-MASHLAHAH: Jurnal Hukum Islam dan Pranata Sosial Islam. 06(01), hlm. 50 
Allah yang mengetahui bahwa transaksi tersebut dilakukan oleh para pelakunya dalam rangka ingin mengelak dari perbuatan riba. ${ }^{18}$

Hal ini dikemukakan juga oleh salah seorang ulama kontemporer yang bernama Wahbah ibn Mușțafā AlZuhailī dalam kitab tafsirnya yang berjudul AlTafsīr Al-Wașịt mengatakan ketika mengomentari firman Allah dalam alQur`an Surat Al-Nisa' Ayat 29 bahwa ayat ini mengharamkan perbuatan zalim atau melampaui batas terhadap harta dan jiwa. Di mana tidak dihalalkan seseorang memakan harta orang lain dengan cara yang batil. Yaitu cara yang tidak disyariatkan dan diambil dari jenis-jenis harta atau manfaatmanfaat suatu komoditas secara zalim tanpa adanya imbalan.

Secara umum keterikatan prinsip syariah khusus terkait equity Crowdfunding yang menjadi pegangan yaitu:

1. Tidak mencari rezeki pada sektor usaha haram, baik dari segi zatnya (objeknya) maupun prosesnya (memperoleh, mengolah dan medistribusikan), serta tidak mempergunakan untuk hal-hal yang haram;

2. Tidak menzalimi dan tidak pula dizalimi (la taẓlimūn wa lā tuẓlamūn);

3. Keadilan pendistribusian pendapatan;

4. Transaksi dilakukan atas dasar rida sama rida tanpa ada paksaan;

5. Tidak ada unsur riba, maysīr (perjudian), gharar (ketidakjelasan), tadlis (penipuan), darar

18 Abū Al-Fidā Ismā'îl ibn ‘Umar ibn Katsīr Al-Qurashī Al-Bașrī Tsumma AlDimashqī. (1999). Tafsīr Al-Qur`ān Al-'Aẓīm. Juz: 2, Taḥqīq: Sāmī ibn Muḥammad Salāmah, Dār Al-Ṭaibah, hlm. 268 (kerusakan/kemudaratan) dan tidak mengandung maksiat.

\subsection{Shariah Compliance di Indonesia}

Shariah compliance merupakan salah satu bentuk kepatuhan perusahaan khususnya perbankan syarieeah terhadap prinsip-prinsip Syariah. Shariah compliance adalah indikator Islamicity Disclosure Index (IDI) yang relevan sebagai bentuk pertanggungjawaban penyediaan informasi kepatuhan Syariah. Pernyataan tersebut didukung oleh para akuntan dan manajer bank Syariah (seperti yang dinyatakan oleh Asrori). Syariah compliance memperkuat mekanisme kepatuhan Syariah dan memastikan bahwa semua peraturan perbankan Syariah relevan dipenuhi. Syariah compliance merupakan salah satu bentuk pengendalian untuk menuntun apakah lembaga Syariah telah menjalankan prinsip-prinsip Syariah atau dapat disebut upaya dalam menciptakan kepatuhan Syariah. ${ }^{19}$

kepatuhan Syariah adalah sistem kepatuhan yang memiliki penekanan khusus pada aspek Syariah dengan ketentuan yang relevan dari hukum, aturan, peraturan, kebijakan, dan prosedur yang terkait dengan Perbankan Syariah perlu dimasukkan ke dalam proses IBI sedemikian rupa sehingga pemantauan dan peninjauan masalah yang terkait dengan kepatuhan Syariah membentuk bagian dari struktur kontrol internal. Shariah Compliance tidak

19 Angriani, Ambo Asse, dkk, Penerapan shariah compliance sebagai prinsip sharia governance pada bank muamalat indonesia tbk. Cabang makassar, ALMASHRAFIYAH: Jurnal Ekonomi, Keuangan, dan Perbankan Syariah, Volume 3, Nomor 1, April (2019), Hlm 30 
terlepas dengan nilai-nilai Islam. Hal ini berarti pengungkapan yang dilakukan terhadap informasi yang ada pada perusahaan harus berlandaskan dengan prinsip-prinsip Islam. Kepatuhan Syariah atau shariah compliance berarti mengikuti standar atau hukum yang telah diatur lembaga Syariah yang berwenang menekankan kepatuhan Syariah atau kepatuhan pada prinsipprinsip Syariah. ${ }^{20}$

Penerapan Shariah compliance adalah upaya regulator dan pengawas dalam menciptakan iklim perekonomian yang sesuai dengan prinsip Syariah, dalam hal investasi efek Syariah (sukuk) tidak meninggalkan peran penting dari OJK sebagai regulator dan pengawas serta DSN-MUI sebagai regulator yang berbasis Syariah dan Dewan Pengawas Syariah (DPS) yang mengawasi dan bertanggung jawab semua kegiatan ekonomi berjalan sesuai prinsip Syariah. DPS memiliki fungsi dalam kegiatan screening shariah bagi kegiatan investasi di pasar modal.

Peraturan Otoritas Jasa Keuangan Nomor 35 /Pojk.04/2017 Tentang Kriteria Dan Penerbitan Daftar Efek Syariah. Maka dari itu mengenai signifikansinya prinsip Syariah ini disi lain untuk membedakan dengan pasar modal konvesional, sehingga pemerintah memastikan terjaminnya penerapan prinsip Syariah yang diregulasikan melalui peraturan penjelas lembaga terkait yaitu OJK. Dijelaskan dalam Pasal 2 ayat 1 yaitu Kegiatan dan jenis usaha yang bertentangan dengan Prinsip Syariah di Pasar Modal mencakup antara lain:

1. Perjudian dan permainan yang tergolong judi

${ }^{20}$ Ibid, Hlm 31.
2. Jasa keuangan ribawi

3. Jual beli risiko yang mengandung unsur ketidakpastian (gharar) dan/atau judi (maisir)

4. Memproduksi, mendistribusikan, memperdagangkan, dan/ atau menyediakan antara lain:

a. Barang atau jasa haram zatnya

b. Barang atau jasa haram bukan karena zatnya yang ditetapkan oleh Dewan Syariah Nasional Majelis Ulama Indonesia dan/atau

c. Barang atau jasa yang merusak moral dan bersifat mudarat.

Adapun transaksi yang bertentangan dengan Prinsip Syariah di Pasar Modal mencakup antara lain:

1. Perdagangan atau transaksi dengan penawaran dan/atau permintaan palsu

2. Perdagangan atau transaksi yang tidak disertai dengan penyerahan barang dan/atau jasa

3. Perdagangan atas barang yang belum dimiliki

4. Pembelian atau penjualan atas Efek yang menggunakan atau memanfaaatkan informasi orang dalam dari Emiten atau Perusahaan Publik

5. Transaksi marjin atas Efek Syariah yang mengandung unsur bunga (riba)

6. Perdagangan atau transaksi dengan tujuan penimbunan

7. Melakukan perdagangan atau transaksi yang mengandung unsur suap (risywah); dan

8. Transaksi lain yang mengandung unsur spekulasi (gharar), penipuan (tadlis) termasuk menyembunyikan kecacatan (ghisysy), dan upaya untuk mempengaruhi pihak lain yang mengandung kebohongan (taghrir). 
Penerapan screening sistem pada aspek kuantitatif lebih banyak perhatian khusus, karena berbicara rasio atas percampuran harta yang haram dengan yang halal. Ini sudah menjadi perdebatan, dimana pada awalnya para ulama mengharamkan investasi pada instrument yang masih mengandung unsur haram dalam sebagian aktivitas bisnisnya. Senada dengan pernyataan Ali Ahmed al-Salus ${ }^{21}$ menegaskan bahwa berinvestasi saham di perusahaan yang melakukan aktivitas halal tetapi masih beroperasi pada sebagian pekerjaan yang haram seperti menggunakan modal kerja berbasis bunga adalah haram. ${ }^{22}$

\subsection{Sukuk dalam Securities Crowdfunding \\ Pada perkembangannya di} Indonesia, crowdfunding bertujuan saling membantu sesama makhluk sosial, dengan bantuang teknologi, dengan begitu transaksi keuangan dalam bentuk teknologi dikategorikan kedalam financial technology. Baik itu berbentuk pembayaran (payment), peminjaman (lending), perencanaan keuangan (personal finance), pembiayaan (crowdfunding), dan lain sebagainya. Financial technology dapat digolongkan menjadi tiga tipe, yaitu:

1. Third-party payment systems,
merupakan sistem pembayaran melalui pihak ketiga. Contoh: sistem pembayaran mobile, platform pembayaran yang menyediakan jasa seperti transfer dan pembayaran bank,

${ }^{21}$ Andri Soemitra, Masa Depan Pasar Modal Syariah Di Indonesia, (Jakarta:

PrenadaMedia: 2014), hlm. 115.

22 Sugiono, Signifikansi Screening System pada Pasar Modal Syariah di Indonesia, Jurnal Azzarqa'; jurnal Hukum Bisnis Islam, Vol. 12., No. 1, Juli 2020. Hlm. 78.
2. Peer to Peer (P2P) Lending, merupakan platform yang mempertemukan pihak yang kelebihan dana dengan pihak yang membutuhkan dana melalui internet. Jadi platform ini memberikan jasa kepada kreditur dan debitur untuk membantu memenuhi kebutuhannya masing-masing secara efisien.

3. Crowdfunding, merupakan konsep suatu program yang dipublikasikan secara umum melalui internet, yang mana jika masyarakat tertarik dengan konsep tersebut akan memberikan dukungan secara finansial, dan investor akan mendapatkan imbalan sesuai kesepakatan.

Pada mulanya Otoritas Jasa Keuangan membagi Crowdfunding menjadi 3 bagian, yakni : pertama, Crowdfunding berbasis donasi atau hadiah adalah penggalangan dana dilakukan dalam bentuk donasi, dengan hadiah tertentu diberikan pada yang menyumbang, tergantung tingkat sumbangannya. Crowdfunding jenis tersebut yang pada umumnya sudah berjalan di Indonesia. Kedua, Crowdfunding berbasis pinjaman, dalam skema ini dana yang diserahkan adalah pinjaman dari masyarakat yang harus dikembalikan dengan skema tertentu. Ketiga, Crowdfunding berbasis equitas, dalam skema ini dana dari masyarakat mendapatkan imbalan berupa persentase saham dari proyek yang digelar. ${ }^{23}$ Namun seiring berjalannya perkembangan teknologi menawarkan kemudahan tepat pada maret 2020 kehadirian securitis crowdfunding menjadi wajah baru bagi dunia fiansial

23 Aprillia Ika, "OJK Segera Keluarkan Aturan Crowdfunding",
www.ekonomi.kompas.com, diakses 31 oktober 2019 
teknologi. Kehadiran securities crowdfunding di Indonesia ditandai dengan pembuatan peraturan yang mengatur tentang penawaran penawaran efek melalui urunan dana berbasis teknologi infromasi oleh otoritas jasa keuangan yang diselipkan pada nomor 57 / POJK. 04/ tahun 2020.

Berbeda dengan sukuk pada umumnya securities crowdfunding adalah salah satu system penawaran efek berbasis tekhnologi informasi, system ini berkembang dimasyarakat seiring dengan waktu sehingga melalui otoritas jasa keuangan melakukan upaya pengawasan dengan membentuk aturan hukum bagi pihak-pihak yang melakukan transaksi efek dengan system securities crowdfunding. Layanan Urun Dana Melalui Penawaran Efek Berbasis Teknologi Informasi (Securities Crowdfunding) bergerak dalam jenis efek yang sudah ditentukan yakni berupa efek bersifat ekuitas, efek bersifat utang, dan sukuk (efek Syariah) merupakan pihak yang memiliki hubungan hukum antara tiga pihak yaitu:

1) Penyelenggara

Penyelenggara Layanan Urun Dana yang selanjutnya disebut Penyelenggara adalah badan hukum Indonesia yang menyediakan, mengelola, dan mengoperasikan Layanan Urun Dana. Badan hokum yang dimaksud yakni berbentuk perseroan terbatas atau koperasi sedangkan koperasi hanya dibatasi bergerak dalam bidang jasa.

2) Penerbit

Penerbit adalah badan usaha Indonesia baik yang berbentuk badan hukum maupun badan usaha lainnya yang menerbitkan Efek melalui Layanan Urun Dana. Penerbit tidak bisa menghimpun dana lebih dari 10 miliar

3) Pemodal

Pemodal adalah pihak yang melakukan pembelian Efek Penerbit melalui Layanan Urunan dana.

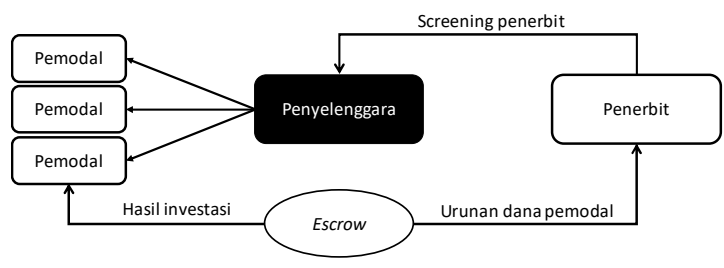

Pada tabel bisa kita penerbit melakukan screening terlebih dahulu kepada penyelenggara mengenai proposal produk yang akan diinfokan melalui platform (penyelenggara) jika lulus screening maka penyelenggara menwarakan kepada publik produk tersebut. Selanjutnya, pemodal akan mengirimkan modal investasinya melalui escrow account atau pihak ketiga yang menjamin penggunaan modal tersebut sekaligus sebagai perantara untuk diberikan kepada penerbit. Setelah waktu yang disepakati penerbit memberikan hasilnya melalui escrow account kepada pemodal.

Sedangkan, Sukuk dalam securities crowdfunding sebagai salah satu produk telah memiliki aturan yang sudah dipublis sejak maret tahun 2020 pada aturan POJK nomor 57 tahun 2020 setiap kegiatan sukuk harus sesuai dengan prinsip syariah, dalam hal ini peran DPS sangat penting sehingga disebutkan dalam aturan tersebut untuk menjaga kepatuhan syariah pada investasi sukuk, yang mana DPS menggunakan aturan DSN-MUI sebagai dasar screening bagi penerbit yang ingin menjalankan investasi sukuk.

\section{KESIMPULAN DAN SARAN}

e-ISSN: 2686-6625 
Sukuk dalam securities crowdfunding adalah Efek syariah berupa sertifikat atau bukti kepemilikan yang bernilai sama dan mewakili bagian yang tidak terpisahkan atau tidak terbagi, atas aset yang mendasarinya. Penawaran sukuk dilakukan melalui urunan dana yang berbasis teknologi informasi kepada publik melalui platform penyelenggara, yang membedakan sukuk dan efek lainnya dalam securities crowdfunding, keharusan memiliki dewan pengawas syariah (DPS) untuk melakukan screening terhadap produk yang dikeluarkan melalui sukuk. Upaya tersebut menjamin kegiatan sukuk dalam securities crowdfunding berjalan sesuai prinsip syariah.

\section{DAFTAR PUSTAKA}

\section{Peraturan}

Pasal 576 Kompilasi hokum Ekonomi Syari'ah, Buku II, edisi 2011.

Peraturan OJK No. 57 /POJK.04/2020 tentang Penawaran Efek Melalui Layanan Urun Dana Berbasis Teknologi Informasi (Securities Crowdfunding).

Buku dan penelitian

AbdulKadir Muhammad, Hukum dan Penelitian Hukum, Cet. 1, Bandung: PT Citra Aditya Bakti, 2004.

Agus Triyanta, "Gharar: Konsep dan Penghindarannya pada Regulasi Terkait Screening Criteria di Jakarta Islamic Index", dalam Jurnal Hukum No. 4 Vol. 172010.

Al-Imam Abul Fida Isma'il Ibnu Katsir Ad-Dimasyqi, Tafsir Ibnu Katsir Juz 3 (Jakarta: Pustaka Imam AsySyafi'i, 2003).
Andri Soemitra, Masa Depan Pasar Modal Syariah Di Indonesia, (Jakarta: PrenadaMedia: 2014).

Angriani, Ambo Asse, dkk, Penerapan shariah compliance sebagai prinsip sharia governance pada bank muamalat indonesia tbk. Cabang makassar, ALMASHRAFIYAH: Jurnal Ekonomi, Keuangan, dan Perbankan Syariah, Volume 3, Nomor 1, April (2019).

Anna Nurlita, "Investasi Di Pasar Modal Syariah Dalam Kajian Islam," Kutubkhanah: Jurnal Penelitian Sosial Keagamaan, 17.1 (2015).

Aprillia Ika, "OJK Segera Keluarkan Aturan Crowdfunding", dalam www.ekonomi.kompas.com, diakses 31 oktober 2019

Beta Pujangga Mukti, "Strategi Ketahanan Pangan Nabi Yusuf: Studi Analisis tentang Sistem Ketahanan Pangan

Diana Wiyanti, "Perspektif Hukum Islam terhadap Pasar Modal Syariah Sebagai Alternatif Investasi Bagi Investor," Ius Quia Iustum Law Journal, 20.2 (2013).

Galih Pamenang Suryo Negoro berjudul "perlindungan hukum konsumen di indonesia ditinjau dari perspektif hukum Islam", Tesis, Hukum Bisnis, Magister Ilmu Hukum, Fakultas Hukum Universitas Islam Indonesia, 2017. Yogyakarta.

Gunawan, S., Malkan, M., \& Jalil, A. (2019). Peranan Kantor Perwakilan Bank Indonesia Provinsi Sulawesi Tengah Dalam 
Upaya Meningkatkan

Penggunaan Uang Logam. Jurnal Ilmu Perbankan dan Keuangan Syariah, 1(1), 57-72.

Gustaf Josua, Moch Zairul Alam, dkk. Tinjauan yuridis terhadap penerapan prinsip keterbukaan dan mitigasi resiko pada equity crowdfunding di indonesia, jurnal hukum universitas brawijaya, desember 2018.

Nabi Yusuf dalam Al-Quran Surat Yusuf Ayat: 46-49," TARJIH: Jurnal Tarjih dan Pengembangan Pemikiran Islam, 16.1 (2019).

Nurdin, N., \& Mir'atun, M. a. (2018). Do Government And Private Sharia Commercial Banks Practice Similar Financial Social Responsibility Disclosure. Hunafa: Jurnal Studia Islamika, 15(2), 285321.

Iswi Hariyani dan Cita Yustisia, Kajian Hukum Bisnis Jasa Crowdfunding Properti, Jurnal; Legislasi Indonesia Vol 16 No.1, Maret 2019.

Peter Mahmud Marzuki, Penelitian Hukum, Cet. 2, Jakarta: Kencana 2008.

Rahmadiani Putri Nilasari, "Perlindungan Hukum Terhadap Investor Dalam Transaksi Jual Beli Efek Melalui Internet", (Yuridika: Volume 26 No 3, SeptemberDesember 2011)

Ratna Hartanto, Hubungan Hukum Para Pihak Dalam Layanan Urun Dana Melalui Penawaran Saham Berbasis
Teknologi Informasi, Jurnal Hukum Ius Quia Iustum; Volume 27 Issue 1, Januari 2020.

Riski Pebru Ariyanti, Aprillaili Aya Tri Kartini, dkk. tinjauan yuridis terhadap perlindungan pemodal platform crowdfunding

Website

https://idcloudhost.com/crowdfunding -pengertian-ciri-ciri-syarat-dancontohnya. Diakses 2 Juni 2021.

https://accurate.id/ekonomikeuangan/ crowdfunding-tujuan-jenis-danmanfaatnya-pada-ekonomibisnis/Diakses 2 Juni 2021. 